\title{
Global review of the Devonian-Carboniferous Boundary: an introduction
}

\author{
Markus Aretz $^{1}$ (D) $\cdot$ Carlo Corradini $^{2}$
}

Published online: 13 June 2021

(C) Senckenberg Gesellschaft für Naturforschung and Springer-Verlag GmbH Germany, part of Springer Nature 2021

The stability of our stratigraphic schemes is an important task for the geoscience community in order to provide a solid temporal framework and calendar for the description and reconstruction of Earth's history and geological processes. The International Commission on Stratigraphy (ICS) via its subcommissions has and continues to put a large effort into this task in defining Global Boundary Stratotype Sections and Points (GSSPs) as global references. This results in an impressive and globally accepted chronostratigraphic zonation for the Phanerozoic and Precambrian (see the charts on stratigraphy.org). So, we can assume that once the long process of establishing a GSSP has been closed, stratigraphic stability for this boundary has been achieved and that a powerful stratigraphic instrument has become available for the geoscience community.

Although the golden spike is a powerful symbol for finality and stability, a GSSP is not set in stone. Stratigraphy and also its timescales are only summarising the current state of knowledge, and since this knowledge is continuously progressing and new techniques and concepts become available, we have to adapt and integrate these new data in our schemes. The DevonianCarboniferous Boundary (DCB), corresponding to the base of the Carboniferous Period, is a good example for such a scenario.

In fact, the definition of the base of the Carboniferous Period at the Second Heerlen Congress in 1935 (Jongmans and Gothan, 1937) is the first internationally and widely recognised chronostratigraphic boundary, hence the first GSSP in our modern understanding. In the deeper-water cephalopod facies of the Rhenish Mountains (Germany), a section

This is the editorial to the special issue "Global review of the DevonianCarboniferous Boundary"

Markus Aretz

markus.aretz@get.omp.eu

1 Géosciences Environnement Toulouse, UPS, CNRS, IRD, 14 Avenue Edouard Belin, 31400 Toulouse, France

2 Dipartimento di Matematica e Geoscienze, Università di Trieste, via Weiss 2, 34128 Trieste, Italy
— Ober-Röddinghausen in the Hönne Valley — and a point - the base of the Gattendorfia Zone represented by the FAD of the goniatite Gattendorfia subinvoluta - were selected to define the base of the Carboniferous by an international board, what was later to become the Commission on Carboniferous Stratigraphy (ICS was not existing at this time).

The Ober-Röddinghausen stratotype already highlighted the importance of the sections in the Rhenish Mountains for the stratigraphic division and subsequent discussions of the latest Devonian-earliest Carboniferous time. This is the consequence of a long tradition of studying the DCB in that region and resulting in a very detailed knowledge. This perception is highlighted in ideas like "time-specific facies" (e.g. Walliser, 1984) and "Rhenish Standard Succession" (e.g. Becker et al., 2016), which emphasise the importance of the Rhenish sections for global correlation. Today, the local lithostratigraphic units of the northern Rhenish Mountains have often lost their original lithostratigraphic connotation and they have become chronostratigraphic time markers. Thus, names like Hangenberg Sandstone (or strata named as equivalents of the Hangenberg Sandstone) have not only been used around the globe, but they are thought to set distinctive time markers.

In the 1960 s and 1970 s, the arrival of fine-scaled biostratigraphy using conodonts brought to light a hiatus at the boundary level in the Ober-Röddinghausen section (Alberti et al. 1974). Hence, the Ober-Röddinghausen stratotype was abandoned and the search for a new stratotype started. The IUGS working group responsible for the new stratotype used as stratigraphic marker the first occurrence of the conodont Siphonodella sulcata, which immediately precedes the entry of Gattendorfia in the Hönne Valley (Paproth and Streel, 1984).

The GSSP (Paproth et al., 1991) for the base of the Tournaisian Stage, hence the base of the Carboniferous System, was defined in the La Serre E' section (Montagne Noire, southern France) (Fig. 1). According to a morphometric study of the supposedly preserved Si. praesulcata-Si. sulcata 


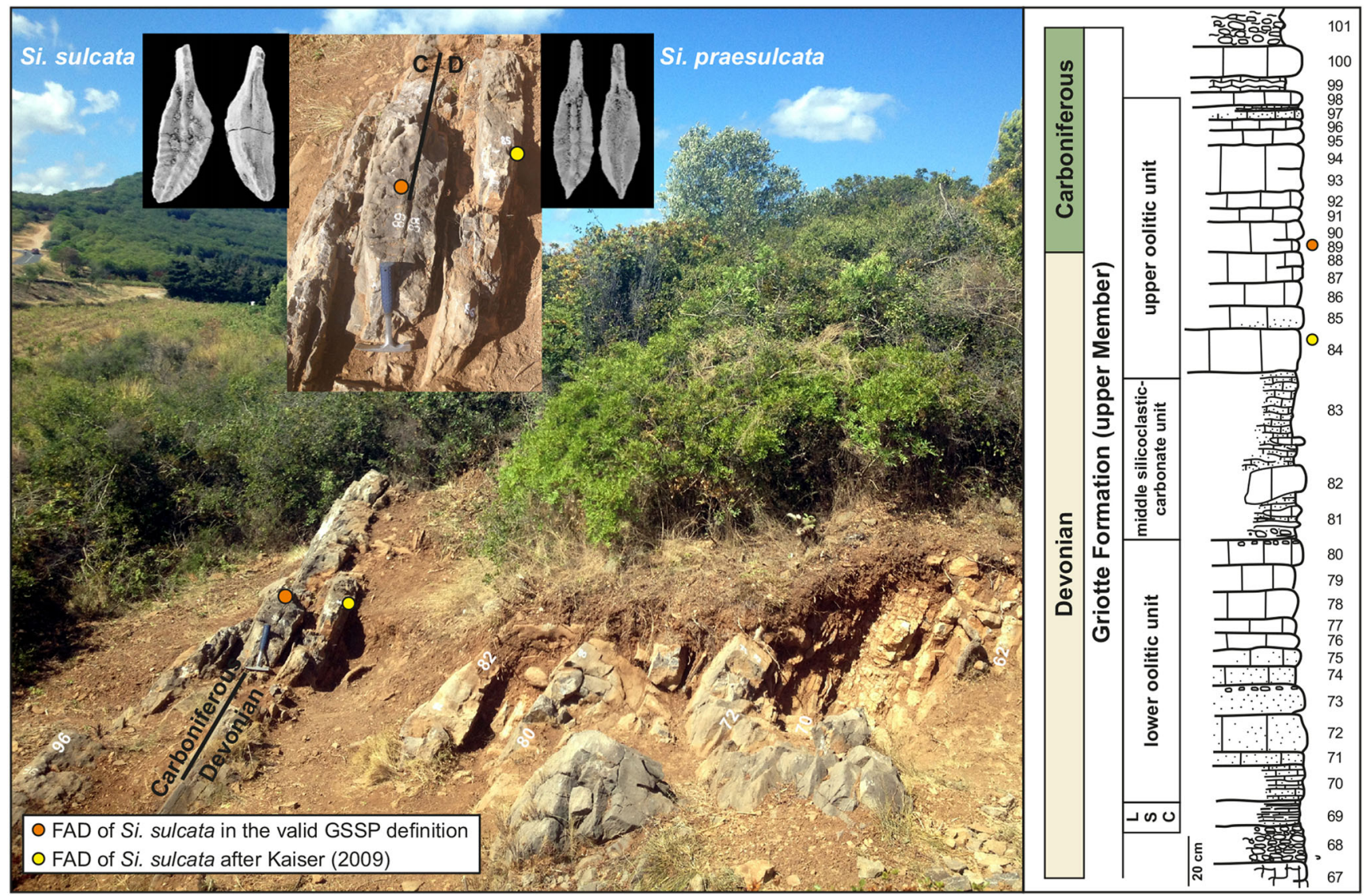

Fig. 1 Graphical mosaic summarising the important information of the valid GSSP at La Serre, southern France: photo of the section (cleaned in 2016), close-up on the boundary interval, photos of the critical conodont species, position of the biostratigraphic index, and the section log modified from Paproth et al. (1991)

lineage (Flajs and Feist 1988), the FAD of Si. sulcata in bed 89 of this section indicates the base of the Carboniferous (Fig. 1). The strata straddling the DCB is a $3.7-\mathrm{m}$ thick unit composed of well-bedded, graded biodetrital limestones. This unit is divided into two oolitic intervals (beds 70-80, 84-98) separated by a clay-rich level (beds 81-83) with reworked blocks and pebbles. Many of the limestone beds show variations in bed thicknesses and restricted lateral traceability pointing to channelised deposits in a high-energy environment.

Already during the selection process of the new GSSP, the section had been criticised (e.g. Ji, 1987; Ziegler and Sandberg, 1996) for its shallow-water nature including reworked fauna and strata, and especially the possible presence of Si. sulcata below bed 89. Ziegler and Sandberg (1996) already formally identified Si. sulcata in bed 85 . Later, Kaiser (2009) found the index species several centimetres lower in bed $84 \mathrm{~b}$ (upper part of bed 84 ). Hence, with the occurrence of the marker fossil below the GSSP just above a lithological change, the definition of the base of the Carboniferous came back on the agendas of the Devonian and Carboniferous subcommissions. At the same time, difficulties in discriminating the marker from its ancestor $\mathrm{Si}$. praesulcata and from the several morphs of early siphonodellids were evidenced (Kaiser and Corradini, 2011), and studies on other conodont taxa important for the stratigraphy across the boundary levels were enhanced (e.g. Protognathodus, Corradini et al., 2011). It is evident that profound and widely accepted understandings of the morphological variability of the biological markers is the only possible solid base for a successful global boundary, since otherwise the (bio)stratigraphic information becomes too dependent from the taxonomical concept of an individual researcher.

A joined SDS/SCCS task group was established in 2009 to redefine the base of the Carboniferous and thus to regain stratigraphic stability in this critical interval of Earth's history. Task group members and other researchers have been active in various aspects related to the boundary definition, and a huge amount of new data has become available (e.g. Corradini et al., 2017; Davydov, 2020; Kaiser et al., 2015; Marshall et al., 2020; Prestianni et al., 2016). Characteristic for many studies are multi-disciplinary approaches, which combine palaeontological, sedimentological, geochemical and petrophysical methods and data (e.g. Bábek et al., 2016; Kumpan et al., 2014; Matyja et al., 2015).

The past and present boundary stratotypes have given a lot of attention to the deeper water facies (slope and basinal 
settings) and its faunal elements, which have been judged to represent the best potential for undisturbed continuous successions and nektonic faunal elements ensuring a wide palaeobiogeographical distribution of marker taxa. This focus has at least two pitfalls. The first is conceptual. It directs the focus of the DCB discussion to a particular facies (deep water "pelagic" facies) and faunal groups (conodonts, ammonoids), and the data coming from elsewhere gain less attention or are completely put aside. This renders global correlation more difficult if not impossible. The second pitfall is the supposed continuous sedimentary record, and hence a complete stratigraphic record. This seems to be a rather obvious simplification, because low sedimentation rates invariably resulted in condensation, hardgrounds and/or (cryptic) hiatuses. It also points to the problem that sampling strategies may not be adequate to achieve the predicted temporal resolution and precision, because a single bed can represent a rather long time. Hence, the discussions of the DCB and its stratotype have to take into consideration very different facies realms, if possible from at least the majority of the palaeocontinents and palaeoclimatic belts, in order to approach the very ambitious aim of a truly global applicable approach and definition. In this respect, it might sometimes be necessary to take a step back and to put the practicability of the boundary for the wide geoscience community on the forefront of the discussion.

The Devonian-Carboniferous transition is marked by major perturbations in the geosphere (palaeoclimate, geochemical cycles, relative sea-level changes) and biosphere (extinctions and radiations) (e.g. Carmichael et al., 2016; Kaiser et al., 2015; Kalvoda et al., 2019; Marshall et al., 2020; Rakociński et al., 2020, 2021). The name Hangenberg Crisis has been coined for this time of major changes. Hence, a good understanding of the dynamics of the crisis is important for any definition of the $\mathrm{DCB}$, but most importantly for the definition of the DCB, the geoscience community has to agree when this crisis starts and when it ends.

The Hangenberg Crisis is equalled with important turnovers in the faunal and flora records, and Kaiser et al. (2015) qualified it as a 1st-order mass extinction. However, it must be stressed that the Hangenberg extinction is not a single short event, which would mark a perfect point in time. It corresponds to a timespan starting in the very latest Devonian and reaching (slightly) into the earliest Carboniferous. The crisis is multi-phased, and it contains not only several marked extinctions, but also radiations of particular taxa. Any definition of the boundary has to ensure that the major extinction levels in the marine realm remain in the Devonian to avoid that taxa traditionally restricted to the Devonian would become extinct in the Carboniferous. Hence, the lowest possible datum is theoretically set. This datum excludes the proposal of Davydov (2020) to use as GSSP a very accurately dated ashlayer below the Hangenberg Black Shale in the Kowala Quarry in Poland. The upper datum is similarly set, since the
Carboniferous radiation of most taxa should not start in the Devonian. This indicates that the DCB should be best placed within the later stages of the Hangenberg Crisis. Kaiser et al. (2015) divided the crises into three intervals, which are precised further in the detailed calendar of Becker et al. (2021, this issue).

One consistent problem in the interpretation of the Hangenberg Crisis is related to the completeness of fossil records and timing of extinctions due to different ideas on sea-level fluctuations and resulting sequence stratigraphic interpretations (Aretz, 2020). In the Rhenish standard succession (e.g. Kaiser et al., 2015), the lower crisis interval starts with a minor regression (top Wocklum Limestone) followed by a rapid transgressive pulse, which resulted in the deposition of the Hangenberg Black Shale, which also contains the maximum flooding surface. The following regression is documented in the middle crisis interval, corresponding to the Hangenberg Shale and Sandstone. The maximum regression is reached near or at the top of the Hangenberg Sandstone. The upper crisis interval corresponds to the following sea-level rise resulting in the deposition of the Stockum Limestone. The sea-level drop in the middle crisis interval is interpreted as a third-order sequence boundary (e.g. Herbig, 2016; Kaiser et al., 2015), which may have reached up to $100 \mathrm{~m}$ deduced from incised valleys. This important drop in sea-level is then put forward to conclude important stratigraphic gaps in the shallow-water realm due to subaerial exposure and inferred erosion during most of the time represented by the Hangenberg Sandstone in the Rhenish Massif (e.g. Van Steenwinkel, 1990).

However, growing evidences arising from modern sedimentological and biostratigraphic work show much more complete records in the shallow water realm (Poty, 2016, Denayer et al., 2021, this issue). The entire pre-extinction to post-extinction succession in Belgium belongs to a single third-order sequence. This highlights the unique, sudden and disruptive nature of the Hangenberg Crises as an out-ofsequence event of the general relative sea-level history in the Devonian-Carboniferous transition. It also points to a distinct temporal offset between the major extinctions in the deeper and shallow water marine facies. Most of the "pelagic" fauna disappeared with the onset of the anoxic to dysoxic conditions in the lower crisis interval, whereas the shallow water fauna survived until the major regression at the top of the middle crisis interval.

In consequences, the Hangenberg Crisis as the "Natural Devonian Carboniferous Boundary" (Walliser, 1984) offers a very good tool to approximately place the DCB based on sedimentological, geochemical, petrophysical and palaeontological data in very different facies realms. This approximation is sufficient for many geological questions, but when high-precision data are required, its timespan is far too long. However, as developed further down, timelines and events in 


\begin{tabular}{|c|c|c|c|c|c|c|c|c|c|}
\hline \multirow{2}{*}{$\begin{array}{l}\sum_{u} \\
\frac{5}{5} \\
i \\
\omega\end{array}$} & \multirow{2}{*}{ 岁 } & \multicolumn{2}{|c|}{ CONODONTS } & \multirow{2}{*}{ 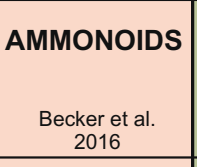 } & \multirow{2}{*}{$\begin{array}{l}\text { SPORES } \\
\text { Streel et al. } 1987 \\
\text { Prestianni et al. } \\
2016 \\
\end{array}$} & \multicolumn{2}{|c|}{ FORAMINIFERS } & \multirow{2}{*}{$\begin{array}{c}\text { RUGOSE } \\
\text { CORALS } \\
\text { Poty et al. } 2006 \\
\text { Denayer et al. } \\
2021 \\
\end{array}$} & \multirow{2}{*}{$\begin{array}{l}\text { HANGENBERG } \\
\text { CRISIS } \\
\\
\text { Becker et al. } \\
2021 \\
\end{array}$} \\
\hline & & $\begin{array}{c}\text { Corradini et al. } \\
2017,2021\end{array}$ & $\begin{array}{l}\text { Becker et al. } \\
2016,2021\end{array}$ & & & $\begin{array}{l}\text { Kulagina et al. } \\
2021\end{array}$ & $\begin{array}{c}\text { Poty et al. } 2006 \\
\text { Denayer et al. } \\
2021\end{array}$ & & \\
\hline \multirow{6}{*}{ 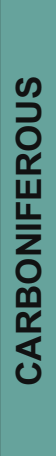 } & \multirow{6}{*}{$\begin{array}{l}\frac{c}{\frac{\pi}{0}} \\
\frac{\sqrt{0}}{\sqrt{0}} \\
\frac{5}{5} \\
\frac{0}{0}\end{array}$} & \multirow{2}{*}{ Si. sandbergi } & \multirow{2}{*}{$\begin{array}{c}\text { Si. (Si) } \\
\text { sandbergi }\end{array}$} & Zadelsdorfia & \multirow{4}{*}{ HD } & Chernyshinella & \multirow{4}{*}{ MFZ 2} & \multirow{5}{*}{$\mathrm{RC} 1 \beta$} & \multirow{6}{*}{$\begin{array}{l}\text { post- } \\
\text { crisis } \\
\text { Interval }\end{array}$} \\
\hline & & & & Pseudarietites & & & & & \\
\hline & & Si. jii & Si.(Si.) mehli & \multirow[b]{2}{*}{ Paprothites } & & \multirow{3}{*}{$\begin{array}{l}\text { Earlandia } \\
\text { minima }\end{array}$} & & & \\
\hline & & Si. duplicata & Si.(Si.) duplicata & & & & & & \\
\hline & & Si. bransoni & Si.(Eosi.) bransoni & & \multirow{3}{*}{ VI } & & \multirow{3}{*}{$\begin{array}{l}\text { MFZ } 1 \\
\text { DFZ } 8\end{array}$} & & \\
\hline & & \multirow{2}{*}{ Pr. kockeli } & $\begin{array}{l}\text { Si. (Eosi.) } \\
\text { sulcata s.l./ } \\
\text { Pr. kuehni }\end{array}$ & Gattendorfia & & $\begin{array}{l}\text { Tournayelina } \\
\text { pseudobeata }\end{array}$ & & $R \subset 1 \alpha$ & \\
\hline \multirow{8}{*}{$\begin{array}{l}z \\
z \\
z \\
\text { zo } \\
\text { 岁 } \\
\end{array}$} & \multirow{8}{*}{ 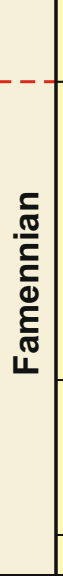 } & & Pr kockeli & Acun & & Quasiendotyhra & & & Upper \\
\hline & & & $\begin{array}{l}\text { Bi. costatus- } \\
\text { Pr. kockeli }\end{array}$ & & \multirow{4}{*}{ LE } & \multirow{7}{*}{$\begin{array}{c}\text { Quasiendotyhra } \\
\text { kobeitusana }\end{array}$} & \multirow{7}{*}{ DFZ 7} & \multirow{7}{*}{$\mathrm{RC} O \beta$} & 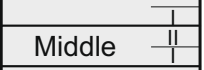 \\
\hline & & $=$ & Interregnum & Postclymenia & & & & & Lower Event \\
\hline & & $\sum_{0}^{\infty}$ & & Wocklumeria & & & & & \begin{tabular}{ll|} 
Prelude & $\| 1$ \\
\end{tabular} \\
\hline & & $\frac{\infty}{\infty}$ & $\begin{array}{l}\text { Si.(Eosi.) } \\
\text { praesulcata }\end{array}$ & Parawocklumeria & & & & & $\begin{array}{l}\text { pre- } \\
\text { crisis }\end{array}$ \\
\hline & & $\overline{2}$ & & Effenbergia & \multirow{3}{*}{ LL } & & & & Interval \\
\hline & & Bi. ultimus & $\begin{array}{l}\text { Bi. ultimus } \\
\text { ultimus }\end{array}$ & M. bisulcata & & & & & \\
\hline & & Bi. costatus & Bi. costatus & Kalloclymenia & & & & & \\
\hline
\end{tabular}

Fig. 2 Correlation scheme of biostratigraphic important fossils groups and calendar of the different phases of the Hangenberg Crises. The dotted red line indicates the timeline for a revised DCB currently discussed by the working group

the latest Devonian and basal Carboniferous inevitably fall into the dynamics of the Hangenberg Crisis, but the establishment of a detailed calendar will provide a very useful finescaled stratigraphic framework (Fig. 2). As different contributions in this issue show, the next challenge for the stratigraphic community is to produce an applicable, universal calendar.

In the last 10 years, the task group met several times in connection with international congresses, and special sessions on the $\mathrm{DCB}$, or formal discussions were held at the 3rd International Palaeontological Congress in London (July 2010), at the SDS/ ISCS field symposium in Morocco (March 2013), at the 2nd International Congress on Stratigraphy (Strati 2015) in July 2015 in Graz, at the Congress on Carboniferous and Permian in Kazan (August 2015), at the IGCP 596 final meeting in Brussels (September 2015) and at the Congress on Carboniferous and Permian in Köln (August 2019). Furthermore, a dedicated workshop with 2 days of discussions and a field trip to the classical sections in Montagne Noire, where the present GSSP is located, was organised in Montpellier in September 2016 (Fig. 3). On that occasion, it was decided to test a possible position of the Devonian/Carboniferous Boundary based on a timeline defined by "the base of the Protognathodus kockeli conodont Zone, the end of the Devonian mass extinction and beginning of the Carboniferous radiation, and the top of a major regression (top of Hangenberg Sandstone)". It has to be stressed that this timeline is based on different criteria, which should increase the potential of placing the boundary in different facies realms and palaeobiogeographical provinces, and increase the practicability of global correlations. The proposed timeline is in accordance to the approach of the task group to reduce the dependence of the boundary definition based on the presence or absence of a single marker (chronostratigraphic units have to be separated from biostratigraphic units!). Hence, the new boundary should be placed not only by characterising the boundary timeline by different criteria, but also by the development of a robust calendar of well-defined timelines slightly below and above the new DCB. Thus, it is not the presence or absence of a single criterion, which may be "too early" or "delayed" in a particular section, but a sequence of arguments for placing the boundary.

The onset of dysoxic and anoxic facies and subsequent extinction of the pelagic and nektonic fauna (often correlated with the base or the Hangenberg Black Shale) is an important timeline in 


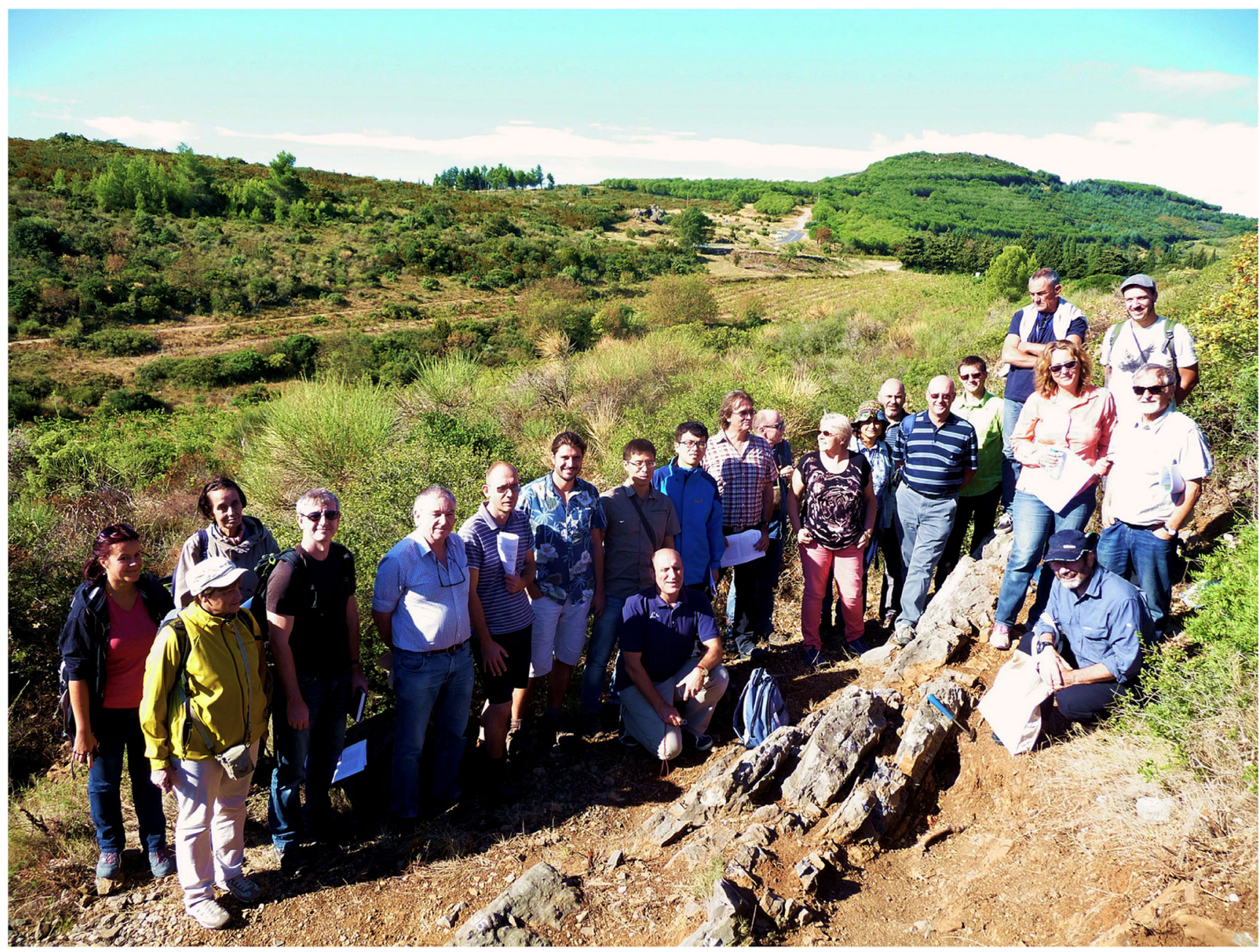

Fig. 3 Group photo of the participants of the DCB workshop in Montpellier (Sept. 2016) taken in the current GSSP section at La Serre. Photo courtesy of F. Lübbecke (Münster)

the latest Devonian and below the proposed new DCB timeline. It is interesting to note that this timeline should be younger than 359.0 Ma according to the data in Davydov (2020), which changes the widely accepted age for the DCB of 359.2 or 359.3 (e.g. Aretz et al., 2020). A timeline characterised by the floral turnover (e.g. extinction of R. lepidophyta) in the continental realm and the income of Si. sulcata (if taxonomic agreement could be reached) and Pr. kuehni in the marine pelagic facies would be a timeline slightly higher above the proposed new boundary level. This timeline fits relatively well to the current GSSP level.

Hence, in constructing a calendar including these and other timelines, we do not only increase chances for precise global correlation, but also offer a powerful tool for the entire geoscience community, and not only the experienced stratigrapher. The proposed boundary level is in accordance to the theoretical lower and upper datum set by our traditional understanding of the geological and biological history around the boundary between the Devonian and Carboniferous systems. Finally, such a boundary would help to maintain stratigraphic stability (Becker et al., 2016).
To avoid any stratigraphic chaos and ambiguity where and how the DCB should be placed in the light of the current ongoing discussions, it has to be stressed that the GSSP at La Serre is still valid and our current reference (Aretz et al., 2020). This would only change in the future if ICS ratifies a different proposal. Hence, the discussions and proposals in the working group are important for our understanding of the latest Devonian-earliest Carboniferous time, and the position of the DCB may change in the future, but nothing has yet been formalised. In any case, in many sections, the proposed criteria by the working group would only slightly lower the boundary.

Before a formal vote on the new position of the $\mathrm{DCB}$, task group members and other scientists were asked to (i) provide regional overviews on the DCB and (ii) check the suitability of the proposed boundary level in their working regions all over the world. This special issue is the result of these studies, and data from various regions are presented in 14 thematic papers authored by a total of 55 experts from all over the world (Fig. 4).

The first contribution by Feist et al. (2021, this issue) is dedicated to the Montagne Noire. Naturally, with the DCB 


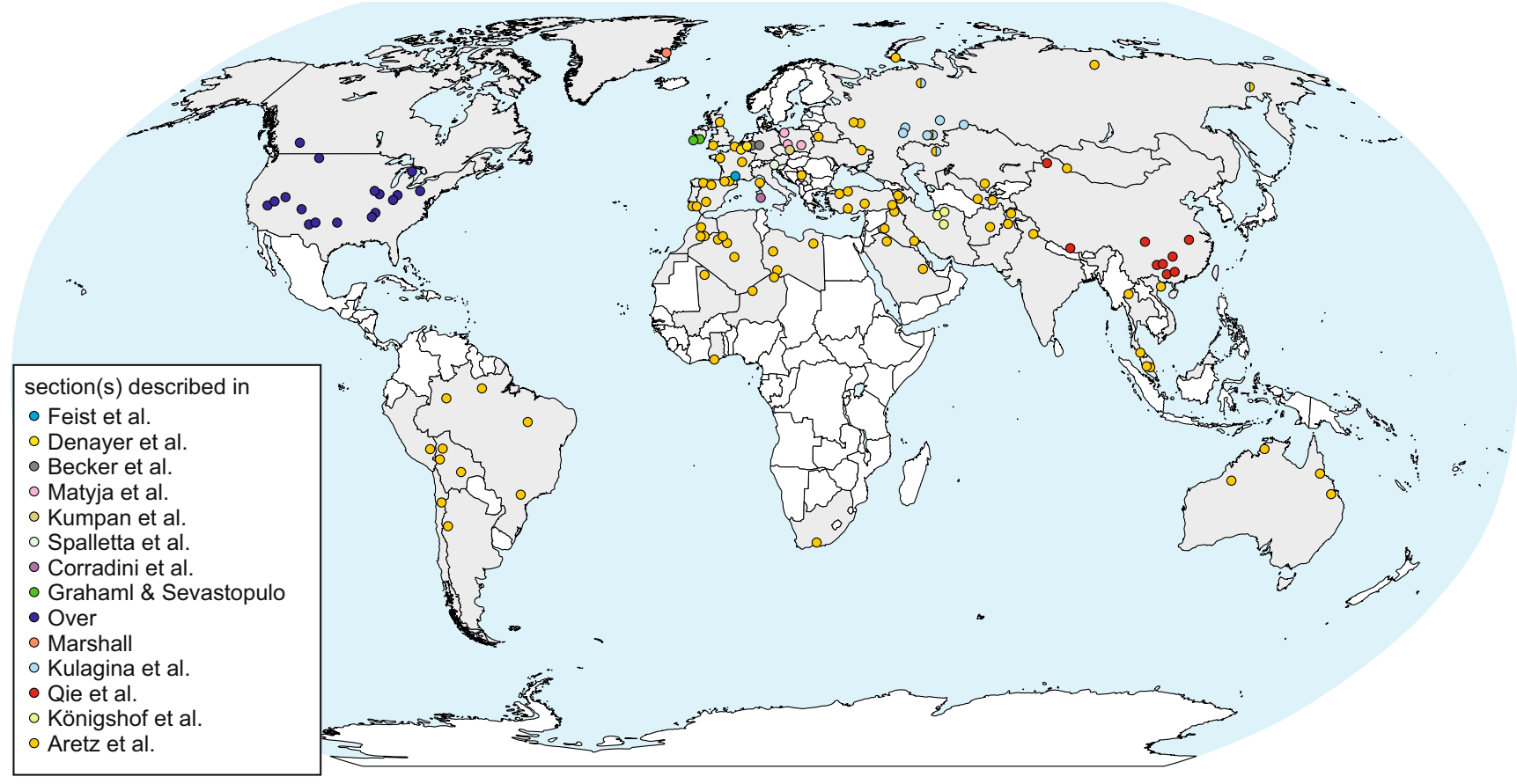

Fig. 4 Geographic distribution of the studied DCB sections on a modern world geography: the countries dealt within this issue are in grey. A dot indicates the approximate position of one or several nearby DCB sections

GSSP situated at La Serre, many papers have already dealt with this region, and a wealth of data is available in the existing literature. However, this study includes new sedimentological interpretation and correlations between the shallow and deeper water sections of the Montagne Noire. (Palaeobiodiversity and Palaeoenvironments 101(2) https://doi.org/10.1007/s12549019-00402-6)

Denayer et al. (2021, this issue) deal with the sections in Belgium and the Avesnois. It provides a lot of new and revised data for this classical region for the DCB in mainly shallow marine facies. As already mentioned above, this study provides new lines of evidences for the completeness of the records, and thus underlines the importance for a holistic approach for the understanding and definition of the DCB (Palaeobiodiversity and Palaeoenvironments 101(2) https:// doi.org/10.1007/s12549-020-00440-5).

Another classical region, the Rhenish Mountains, where numerous DCB sections in deeper water ("pelagic") facies crop out, is dealt with by Becker et al. (2021, this issue). Overall 30 sections are reviewed in detail in terms of litho-, event, conodont, ammonoid, sequence, and chemostratigraphy. A byproduct of this is the refinement of the nomenclature and calendar of the Hangenberg Crisis (Palaeobiodiversity and Palaeoenvironments 101(2) https://doi.org/10.1007/s12549020-00469-6).

Matyja et al. (2021, this issue) described the DCB in Poland. This multidisciplinary study summarises astonishingly detailed data from ramp environments known from the subsurface of Pomerania (western Poland) and the pelagic successions of the
Holy Cross Mountains and Sudetes, where the DCB is found in surface outcrops (Palaeobiodiversity and Palaeoenvironments 101(2) https://doi.org/10.1007/s12549-020-00442-3).

The DCB interval of the Moravian Karst is presented by Kumpan et al. (2021, this issue). Their study presents wellstudied sections, with almost continuous carbonate sedimentation, characterised by carbonate turbidites and hemipelagic successions. From a stratigraphic point of view, the intermixing of faunal markers from the pelagic and neritic realms (conodonts, calcareous foraminifers) provides interesting perspectives (Palaeobiodiversity and Palaeoenvironments 101(2) https://doi.org/10.1007/s12549-019-00409-z).

The review of the DCB sections in the Carnic Alps provided by Spalletta et al. (2021, this issue) showcases a rather unique situation in 2 sections, including the well-known Grüne Schneid. There, a fully carbonated and highly condensed deeper water succession crosses the boundary, and the typical lithological changes related to the Hangenberg Crisis the "pelagic" facies are absent. However, a black shale interval is present in two other sections in the area (Palaeobiodiversity and Palaeoenvironments 101(2) https:// doi.org/10.1007/s12549-019-00413-3).

Corradini et al. (2021, this issue) provide a short overview on the two DCB sections, which are exposed on Sardinia. Both sections show a lithological change in the boundary interval, and detailed data on conodonts and magnetic susceptibility suggest a hiatus just above the black shale interval (Palaeobiodiversity and Palaeoenvironments 101(2) https:// doi.org/10.1007/s12549-019-00411-5). 
The DCB interval in southern Ireland is presented by Graham and Sevastopulo (2021, this issue). In this area, thick successions of siliciclastic rocks are well-exposed in numerous coastal sections with the Old Kinsale Head section being the most famous one. This study shows that the fluvial coastal plain environments of the latest Devonian are replaced by shallow marine strata of earliest Carboniferous age (Palaeobiodiversity and Palaeoenvironments 101(2) https:// doi.org/10.1007/s12549-020-00455-y).

Over (2021, this issue) documents the DCB from various basin with marine strata in North America using conodonts, brachiopods, miospores, carbon isotope data, and magnetic susceptibility data. The boundary is well-constrained and conformable in the Illinois Basin and Oklahoma. It is less wellconstrained in the Appalachian Basin, Antler Foreland, western platform, and the Alberta Platform, and often developed on an unconformity (Palaeobiodiversity and Palaeoenvironments 101(2) https://doi.org/10.1007/s12549-020-00428-1).

In his contribution on Greenland, Marshall (2021, this issue) describes sections straddling the DCB in a terrestrial (lacustrine) setting hundreds of kilometres away from the palaeocoastlines of Laurussia. Information provided for the extinction sequences of the terrestrial microflora are important for the discussions on the correlation between the marine and terrestrial realms (Palaeobiodiversity and Palaeoenvironments 101(2) https://doi.org/10.1007/s12549-020-00448-x).

Kulagina et al. (2021, this issue) review the foraminiferal biostratigraphy of the DCD beds in shallow water carbonated facies in Russia and Western Kazakhstan. The DCB is situated within the Tournayellina pseudobeata-remnant Quasiendothyra Zone. Correlations to ammonoid-based and conodont-based faunal schemes are provided and ensure the correlation in to deeper marine facies (Palaeobiodiversity and Palaeoenvironments 101(2) https://doi.org/10.1007/s12549-020-00439-y).

Sections straddling the DCB in southern China have been reviewed by Qie et al. (2021, this issue). Their multidisciplinary study uses integrated biostratigraphic, event-stratigraphic, and geochemical approaches along a proximal to basinal transect. It provides detailed insights into the Hangenberg Crisis in the different palaeoenvironmental settings, and results in a robust stratigraphic framework for the DCB interval (Palaeobiodiversity and Palaeoenvironments 101(2) https:// doi.org/10.1007/s12549-021-00494-z).

Königshof et al. (2021, this issue) provide an interesting insight into the shallow water settings in which most of the Iranian DCB sections are situated. Biostratigraphic uncertainties in most sections and/or hiatuses in the DCB interval make difficult the correlation of those sections to the standards developed in pelagic/hemipelagic palaeoenvironments (Palaeobiodiversity and Palaeoenvironments 101(2) https:// doi.org/10.1007/s12549-020-00438-z).

The last contribution of this issue by Aretz et al. (2021, this issue) compiles data on the Devonian-Carboniferous Boundary successions from countries and regions, which have not been dealt with separately in this special issue. These necessarily shorter and less detailed compilations than the detailed studies in the other contributions cover a wide geographic range from South America, Africa, Arabia, Asia, Australia, to Europe (Palaeobiodiversity and Palaeoenvironments 101(2) https://doi. org/10.1007/s12549-021-00495-y).

Acknowledgements This special issue has only become possible thanks to the input from many people. We would like to thank all the colleagues who have responded to our solicitations, being it as author or a reviewer. Especially, the latter have done a very good, but not always easy job, and we would like to thank them for their efforts they put into this task. We would like to express our profound thanks to the editorial team at Senckenberg, and in special Sinje Weber who not only always had an open mind for our solicitations, but also has done a tremendous job in getting the manuscripts into actual papers. Last but not least, we would like to thank all the colleagues who have worked on DCB sections and gathered and published data all over the world. They are invaluable for our understanding of the latest Devonian and earliest Carboniferous World.

\section{References}

Alberti, H., Gross-Uffenorde, H., Streel, M., Uffenorde, H., \& Walliser, O. H. (1974). The stratigraphical significance of the Protognathodus fauna from Stockum (Devonian/Carboniferous boundary, Rhenish Schiefergebirge). Newsletter on Stratigraphy, 3, 263-276. https:// doi.org/10.1127/nos/3/1974/263.

Aretz, M. (2020). Late Devonian extinctions. In Alderton, D. \& Elias, S. A. (Eds.) Encyclopedia of geology, 2nd edition, (pp. 628-636). https://doi.org/10.1016/B978-0-12-409548-9.12453-4

Aretz, M., Herbig, H.-G., Wang, X. D., Gradstein, F. M., Agterberg, F. P., \& Ogg, J. G. (2020). Chapter 23 - The Carboniferous period. In J. M. Gradstein, J. G. Ogg, M. D. Schmitz, \& G. M. Ogg (Eds.), Geologic Time Scale 2020 (pp. 811-874). Elsevier. https://doi.org/ 10.1016/B978-0-12-824360-2.00023-1.

Aretz, M., Corradini, C., \& Denayer J. (2021). The DevonianCarboniferous Boundary around the globe: a complement. In M. Aretz \& C. Corradini (Eds.) Global review of the DevonianCarboniferous Boundary. Palaeobiodiversity and Palaeoenvironments 101(2). https://doi.org/10.1007/s12549-021-00495-y. [this issue]

Bábek, O., Kumpan, T., Kalvoda, J., \& Grygar, T. M. (2016). Devonian/ Carboniferous boundary glacioeustatic fluctuations in a platform-tobasin direction: A geochemical approach of sequence stratigraphy in pelagic settings. Sedimentary Geology, 337, 81-99. https://doi.org/ 10.1016/j.sedgeo.2016.03.009.

Becker, R. T., Kaiser, S. I., \& Aretz, M. (2016). Review of chrono-, lithoand biostratigraphy across the global Hangenberg Crisis and Devonian-Carboniferous Boundary. In R. T. Becker, P. Königshof, \& C. E. Brett (Eds.), Devonian climate, sea level and evolutionary events (Vol. 423, pp. 355-386). Special Publications Geological Society of London. https://doi.org/10.1144/SP423.10.

Becker, R. T., Hartenfels, S., \& Kaiser, S. I. (2021). Review of DevonianCarboniferous Boundary sections in the Rhenish Slate Mountains (Germany). In M. Aretz, \& C. Corradini (Eds.) Global review of the Devonian-Carboniferous Boundary. Palaeobiodiversity and Palaeoenvironments 101(2). https://doi.org/10.1007/s12549-02000469-6. [this issue]

Carmichael, S. K., Waters, J. A., Batchelor, C. J., Coleman, D. M., Suttner, T. J., Kido, E., Moore, L. M., \& Chadimová, L. (2016). Climate instability and tipping points in the Late Devonian: 
Detection of the Hangenberg Event in an open oceanic island arc in the Central Asian Orogenic Belt. Gondwana Research, 32, 213 231. https://doi.org/10.1016/j.gr.2015.02.009.

Corradini, C., Kaiser, S. I., Perri, M. C., \& Spalletta, C. (2011). Protognathodus (Conodonta) and its potential as a tool for defining the Devonian/Carboniferous boundary. Rivista Italiana $d i$ Paleontologia e Stratigrafia, 117(1), 15-28. https://doi.org/10. 13130/2039-4942/5960.

Corradini, C., Spalletta, C., Mossoni, A., Matyja, H., \& Over, D. J. (2017). Conodonts across the Devonian/Carboniferous boundary: a review and implication for the redefinition of the boundary and proposal of an updated conodont zonation. Geological Magazine, 154(4), 888-902. https://doi.org/10.1017/S001675681600039X.

Corradini, C., Mossoni, A., Corriga, M. G., \& Spalletta C. (2021). The Devonian/Carboniferous Boundary in Sardinia (Italy). In M. Aretz, \& C. Corradini (Eds.) Global review of the Devonian-Carboniferous Boundary. Palaeobiodiversity and Palaeoenvironments 101(2). https://doi.org/10.1007/s12549-019-00411-5. [this issue]

Davydov, V. I. (2020). Shift in the paradigm for GSSP boundary definition. Gondwana Research, 86, 266-286. https://doi.org/10.1016/j. gr.2020.06.005

Denayer, J., Prestianni, C., Mottequin, B., Hance, L., \& Poty, E. (2021). The Devonian-Carboniferous boundary in Belgium and surrounding areas. In M. Aretz \& C. Corradini (Eds.) Global review of the Devonian-Carboniferous Boundary. Palaeobiodiversity and Palaeoenvironments 101(2). https://doi.org/10.1007/s12549-02000440-5. [this issue]

Feist, R., Corneé, J. J., Girard, C., Corradini, C., Hartenfels, S., \& Aretz, M. (2021). The Devonian/Carboniferous Boundary in the stratotype area (SE Montagne Noire, France). In M. Aretz \& C. Corradini (Eds.) Global review of the Devonian-Carboniferous Boundary. Palaeobiodiversity and Palaeoenvironments 101(2). https://doi.org/10.1007/s12549-019-00402-6. [this issue]

Flajs, G., \& Feist, R. (1988). Index conodonts, trilobites and environment of the Devonian/Carboniferous boundary beds at La Serre (Montagne Noire, France). Courier Forschungsinstitut Senckenberg, 100, 53-107.

Graham, J. R., \& Sevastopulo, G. D. (2021). The stratigraphy of latest Devonian and earliest Carboniferous rocks in Ireland. In M. Aretz \& C. Corradini (Eds.) Global review of the Devonian-Carboniferous Boundary. Palaeobiodiversity and Palaeoenvironments 101(2). https://doi.org/10.1007/s12549-020-00455-y. [this issue]

Herbig, H.-G. (2016). Mississippian (Early Carboniferous) sequence stratigraphy of the Rhenish Kulm Basin, Germany. In Denayer, J. \& Aretz, M. (Eds.) Devonian and Carboniferous research: homage to Professor Edouard Poty, Geologica Belgica, 19, 81-110. https://doi. org $/ 10.20341 / \mathrm{gb} .2016 .010$

Ji, Q. (1987). New results from Devonian-Carboniferous boundary beds in South China. Newsletters on Stratigraphy, 17(3), 155-167. https://doi.org/10.1127/nos/17/1987/155.

Jongmans, W. J., \& Gothan, W. (1937). Betrachtungen über die Ergebnisse des zweiten Kongresses für Karbonstratigraphie. In Jongmans W. J., Deuxième Congrès pour l'avancement des études de stratigraphie carbonifère, Heerlen, Septembre 1935. Compte Rendu, 1, 1-40.

Kaiser, S. I. (2009). The Devonian/Carboniferous boundary stratotype section (La Serre, France) revisited. Newsletters on Stratigraphy, 43(2), 195-205. https://doi.org/10.1127/0078-0421/2009/00430195 .

Kaiser, S. I., \& Corradini, C. (2011). The early siphonodellids (Conodonta, Late Devonian-Early Carboniferous): overview and taxonomic state. Neues Jahrbuch für Geologie und Paläontologie, 261(1), 19-35. https://doi.org/10.1127/0077-7749/2011/0144.

Kaiser, S. I., Aretz, M., \& Becker, R. T. (2015). The global Hangenberg Crisis (Devonian-Carboniferous transition): review of a first-order mass extinction. In R. T. Becker, P. Königshof, \& C. E. Brett (Eds.),
Devonian climate, sea level and evolutionary events (Vol. 423, pp. 387-437). Special Publications Geological Society of London. https://doi.org/10.1144/SP423.9.

Kalvoda, J., Kumpan, T., Qie, W., Frýda, J., \& Bábek, O. (2019). Mercury spikes at the Devonian-Carboniferous boundary in the eastern part of the Rhenohercynian Zone (central Europe) and in the South China Block. Palaeogeography, Palaeoclimatology, Palaeoecology, 531(Part A), 109221. https://doi.org/10.1016/j. palaeo.2019.05.043.

Königshof, P., Bahrami, A., \& Kaiser, S. I. (2021). DevonianCarboniferous boundary sections in Iran. In M. Aretz \& C. Corradini (Eds.) Global review of the Devonian-Carboniferous Boundary. Palaeobiodiversity and Palaeoenvironments 101(2). https://doi.org/10.1007/s12549-020-00438-z. [this issue]

Kulagina, E. I., Zaytseva, E. L., Vevel, Y. A., Stepanova T. I., Gibshman, N. B., Nikolaeva, S. V., Kononova L. I., \& Plotitsyn, A. N. (2021). The foraminiferal zonal scale of the Devonian-Carboniferous boundary beds in Russia and Western Kazakhstan and its correlation with ammonoid and conodont scales. In M. Aretz \& C. Corradini (Eds.) Global review of the Devonian-Carboniferous Boundary. Palaeobiodiversity and Palaeoenvironments 101(2). https://doi. org/10.1007/s12549-020-00439-y. [this issue]

Kumpan, T., Bábek, O., Kalvoda, J., Grygar, T. M., \& Frýda, J. (2014). Sea-level and environmental changes around the DevonianCarboniferous boundary in the Namur-Dinant Basin (S Belgium, NE France): a multi-proxy stratigraphic analysis of carbonate ramp archives and its use in regional and interregional correlations. Sedimentary Geology, 311, 43-59. https://doi.org/10.1016/j. sedgeo.2014.06.007.

Kumpan, T., Kalvoda, J., Bábek O., Grygar, T. M., \& Frýda, J. (2021). The Devonian-Carboniferous boundary in the Moravian Karst (Czech Republic). In M. Aretz \& C. Corradini (Eds.) Global review of the Devonian-Carboniferous Boundary. Palaeobiodiversity and Palaeoenvironments 101(2). https://doi.org/10.1007/s12549-01900409-z. [this issue]

Marshall J. A. (2021). A terrestrial Devonian-Carboniferous boundary section in East Greenland. In M. Aretz \& C. Corradini (Eds.) Global review of the Devonian-Carboniferous Boundary. Palaeobiodiversity and Palaeoenvironments 101(2). https://doi. org/10.1007/s12549-020-00448-x. [this issue]

Marshall, J. E., Lakin, J., Troth, I., \& Wallace-Johnson, S. M. (2020). UV-B radiation was the Devonian-Carboniferous boundary terrestrial extinctions kill mechanism. Science Advances, 6, eaba0768. https://doi.org/10.1126/sciadv.aba0768.

Matyja, H., Sobień, K., Marynowski, L., Stempień-Sałek, M., \& Małkowski, K. (2015). The expression of the Hangenberg Event (latest Devonian) in a relatively shallow-marine succession (Pomeranian Basin, Poland): the results of a multi-proxy investigation. Geological Magazine, 52(3), 400-428. https://doi.org/10. 1017/S001675681400034X.

Matyja, H., Woroncowa-Marcinowska, T., Filipiak, P., Brański, P., \& Sobień, K. (2021). The Devonian/Carboniferous boundary interval in Poland: multidisciplinary studies in pelagic (Holy Cross Mountains and Sudetes) and ramp (Western Pomerania) successions. In M. Aretz \& C. Corradini (Eds.) Global review of the Devonian-Carboniferous Boundary. Palaeobiodiversity and Palaeoenvironments 101(2). https://doi.org/10.1007/s12549-02000442-3. [this issue]

Over, D. J. (2021). The Devonian-Carboniferous boundary in the United States. In M. Aretz \& C. Corradini (Eds.) Global review of the Devonian-Carboniferous Boundary. Palaeobiodiversity and Palaeoenvironments 101(2). https://doi.org/10.1007/s12549-02000428-1. [this issue]

Paproth, E., \& Streel, M. (1984). Precision and practicability: On the definition of the Devonian-Carboniferous boundary. Courier Forschungsinstitut Senckenberg, 67, 255-258. 
Paproth, E., Feist, R., \& Flajs, G. (1991). Decision on the DevonianCarboniferous boundary stratotype. Episodes, 14(4), 331-336. https://doi.org/10.18814/epiiugs/1991/v14i4/004.

Poty, E. (2016). The Dinantian (Mississippian) succession of southern Belgium and surrounding areas: stratigraphy improvement and inferred climate reconstruction. In J. Denayer \& M. Aretz (Eds.) Devonian and Carboniferous research: homage to Professor Edouard Poty, Geologica Belgica, 19, 177-200. https://doi.org/10. 20341/gb.2016.014

Poty, E., Devuyst, F.-X., \& Hance, L. (2006). Upper Devonian and Mississippian foraminiferal and rugose coral zonations of Belgium and northern France: A tool for Eurasian correlations. Geological Magazine, 143, 829-857. https://doi.org/10.1017/ S0016756806002457.

Prestianni, C., Sautois, M., \& Denayer, J. (2016). Disrupted continental environments around the Devonian-Carboniferous boundary: introduction of the tener event. In J. Denayer \& M. Aretz (Eds.) Devonian and Carboniferous research: homage to Professor Edouard Poty, Geologica Belgica 19, 135-145. https://doi.org/10. 20341/gb.2016.013

Qie, W., Sun, Y., Guo, W., Ting, N, Chen, B., Song, J., Liang, K., Yin, B., Han, S., Chang, J., \& Wang, XD. (2021). The DevonianCarboniferous boundary in China. In M. Aretz \& C. Corradini (Eds.) Global review of the Devonian-Carboniferous Boundary. Palaeobiodiversity and Palaeoenvironments 101(2). https://doi. org/10.1007/s12549-021-00494-z. [this issue]

Rakociński, M., Marynowski, L., Pisarzowska, A., Bełdowski, J., Siedlewicz, G., Zatoń, M., Perri, M. C., Spalletta, C., \& Schönlaub, H. P. (2020). Volcanic related methylmercury poisoning as the possible driver of the end-Devonian mass extinction. Scientific Reports, 10, 7344. https://doi.org/10.1038/s41598-02064104-2.
Rakociński, M., Pisarzowska, A., Corradini, C., Narkiewicz, K., Dubicka, Z., \& Abdiyev, N. (2021). Mercury spikes as evidence of extended arc-volcanism around the Devonian-Carboniferous boundary in the South Tian Shan (southern Uzbekistan). Scientific Reports, 11, 5708. https://doi.org/10.1038/s41598-021-85043-6.

Spalletta, C., Corradini, C., Feist, R., Korn, D., Kumpan, T., Perri, M. C., Pondrelli, M., \& Venturini, C. (2021). The Devonian/Carboniferous Boundary in the Carnic Alps (Austria and Italy). In M. Aretz \& C. Corradini (Eds.) Global review of the Devonian-Carboniferous Boundary. Palaeobiodiversity and Palaeoenvironments 101(2). https://doi.org/10.1007/s12549-019-00413-3. [this issue]

Streel, M., Higgs, K., Loboziak, S., Riegel, W., \& Steemans, P. (1987). Spore stratigraphy and correlation with faunas and floras in the type marine Devonian of the Ardenne-Rhenish regions. Review of Palaeobotany and Palynology, 50, 211-229. https://doi.org/10. 1016/0034-6667(87)90001-7.

Van Steenwinkel, M. (1990). Sequence stratigraphy from "spot" outcrops - example from a carbonate-dominated setting: DevonianCarboniferous transition, Dinant synclinorium (Belgium). Sedimentary Geology 69(3-4): 259-280. https://doi.org/10.1016/ 0037-0738(90)90053-V.

Walliser, O. H. (1984). Pleading for a natural D/C boundary. Courier Forschungsinstitut Senckenberg, 67, 241-246.

Ziegler, W., \& Sandberg, C. A. (1996). Reflexions on Frasnian and Famennian stage boundary decisions as a guide to future deliberations. Newsletters on Stratigraphy, 33, 157-180. https://doi.org/10. 1127/nos/33/1995/157.

Publisher's note Springer Nature remains neutral with regard to jurisdictional claims in published maps and institutional affiliations. 